\title{
REPORTE DE CASO: ARTERITIS DE TAKAYASU EN ECUADOR
}

\author{
Álvarez Rocío ${ }^{1 *}$, Ramirez Diana ${ }^{1}$, Villacís Patricia ${ }^{2}$, Acosta Gabriel $^{3}$
}

DOI: $10.48018 /$ rmv.v32.i1.S12

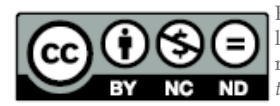

ste artículo está bajo un Este articulo esta bajo una mons de tipo Reconocimiento - No comercial - Sin obras OPEN ACCESS derivadas 4.0 International.

1. Pontificia Universidad Católica del Ecuador. Facultad de Medicina. Posgrado de Medicina Interna. Quito, Ecuador.

2. Pontificia Universidad Católica del Ecuador. Facul tad de Medicina. Carrera de Medicina. Quito, Ecuador. 3. Hospital Vozandes Quito. Médico del Servicio de Medicina Interna. Quito, Ecuador

\section{ORCID ID:}

Álvarez Rocío

orcid.org/0000-0001-9578-890X

Ramirez Diana

orcid.org/0000-0003-4728-3290

Villacís Patricia

orcid.org/0000-0002-0424-7065

Acosta Gabriel

orcid.org/0000-0002-2465-2551

* Corresponding author:

Rocío Álvarez

E-mail: chiotef.91@gmail.com

Article history: Manuscript presented at the I Clinical Case Contest - Hospital Vozandes Quito, February 27, 2021

CARE 2017 Check List statement: The authors have real the CARE 2017 Check List and the manuscript was prepared and revised according to the CARE 2017 Checklist.

Conflict of interest: All authors declared that there are no conflicts of interest.

Financial disclosure: The authors have no financial relationships relevant to this article to disclose.

Forma de citar este artículo: Álvarez $\mathrm{R}$ Ramirez D, Villacís P, Acosta G. REPORTE DE CASO: ARTERITIS DE TAKAYASU EN ECUADOR. Rev Med Vozandes. 2021; 32 (1 Suppl 1): S23-S24

\section{Resumen}

Introducción: La arteritis de Takayasu es una panarteritis, caracterizada por inflamación crónica, que afecta a grandes vasos, especialmente a la Aorta y sus ramas principales. Esta patología es extremadamente rara, tiene mayor incidencia en Japón, presentando baja incidencia en Latinoamérica.

Descripción del Caso: Presentamos el caso de una adulta joven, sin antecedentes de importancia; con cuadro de 3 meses de evolución de cefalea intensa inicialmente catalogada como neuralgia del trigémino y cefalea en racimos, además, pulsos asimétricos y variación en la tensión arterial entre ambas extremidades superiores que permitieron plantearse varios diagnósticos presuntivos. En cuanto a los exámenes complementarios en la paciente se evidenció elevación sostenida de reactantes de fase aguda. Nuestra paciente cumplía con cuatro criterios diagnósticos del Colegio Americano de Reumatología para arteritis de Takayasu y el diagnóstico fue confirmado mediante angioresonancia magnética de cuello, tórax y abdomen, donde se observó afectación de todo el recorrido de la aorta. Con respecto al tratamiento, la terapia de primera línea son los esteroides a altas. En los pacientes en los que la suspensión de los esteroides es difícil, se recomienda la terapia combinada con agentes inmunosupresores. En el caso de nuestra paciente se optó por la terapia combinada con prednisona y metotrexate, con lo cual presentó una evolución favorable.

Conclusión: La arteritis de Takayasu es una vasculitis con poca frecuencia, sin embargo, es importante realizar un diagnóstico y tratamiento oportuno para poder mejorar el pronóstico detener la progresión de la enfermedad y mejorar la calidad de vida de los pacientes que sufren esta patología. 


\begin{tabular}{|l|l|}
\hline & Abstract \\
& CASE REPORT: \\
& TAKAYASU ARTERITIS IN ECUADOR \\
\hline $\begin{array}{r}\text { Keywords: Takayasu arteri- } \\
\text { tis, panarteritis, vasculitis, } \\
\text { case report, Ecuador }\end{array}$ & \\
\hline
\end{tabular}

Introduction: Takayasu's arteritis is a panarteritis, characterized by chronic inflammation, that affects large vessels, especially the Aorta and its main branches. This pathology is extremely rare, has a higher incidence in Japan, presenting low incidence in Latin America.

Case description: We present the case of a young adult, with no significant medical history, who presents a 3 months of evolution intense headache initially classified as trigeminal neuralgia and cluster headache. Asymmetric pulses and variation in blood pressure between both upper extremities where observed which allowed several presumptive diagnoses to be considered.

In the complementary examinations, the patient showed sustained elevation of acute phase reactants. Our patient met four diagnostic criteria of the American College of Rheumatology for Takayasu arteritis and the diagnosis was confirmed by magnetic Angio resonance of the neck, chest and abdomen, where involvement of the entire route of the aorta was observed.

In context to treatment, the first-line therapy is high-dose steroids. In patients in whom the suspension of steroids is difficult, combined therapy with immunosuppressive agents is used. In the case of our patient, combined therapy with prednisone and methotrexate was chosen, which presented a favorable evolution.

Conclusion: Takayasu arteritis is an infrequent vasculitis, however, it is important to make an early diagnosis and treatment in order to improve the prognosis, stop the progression of the disease and improve the quality of life of patients suffering from this pathology. 